\title{
BIOREMEDIATION OF A CRUDE-OIL POLLUTED AGRICULTURAL SOIL AT PORT HARCOURT, NIGERIA
}

\section{M.J. Ayotamuno ${ }^{a}$, R. B. Kogbara ${ }^{a}$, S.O.T. Ogaji ${ }^{\text {b+ }}$, S.D. Probert ${ }^{b}$}

${ }^{a}$ Agricultural \& Environmental Engineering Department, Rivers State University of Science \& Technology, Port Harcourt. P.M.B. 5080, Nigeria

${ }^{\mathrm{b}}$ School Of Engineering, Cranfield University, Bedfordshire. United Kingdom. Mk43

OAL

${ }^{+}$Corresponding author

\begin{abstract}
$\underline{\text { Abstract }}$
A combination of treatments, consisting of the application of fertilizers and oxygen exposure, was evaluated in-situ during a period of six weeks. Conditions of a major spill were simulated by sprinkling crude-oil on experimental cells containing agricultural soil. The remedial treatments were then applied and the soil characteristics analyzed after set periods. Soil physicochemical parameters, such as moisture content, $\mathrm{pH}$ value, electrical conductivity as well as, organic-carbon and total-nitrogen contents showed distinct variations with time. The total heterotrophic bacteria (THB) count in all the treatment cells increased with time. The control cell, $\mathrm{O}$, (which was not treated) indicated no signs of remediation within the study period. The hydrocarbon losses (50 to 95\%) experienced in the five other treatment-cells revealed the effectiveness in degrading the hydrocarbon contaminant. The results of this study indicate that the application of increased concentrations of nutrients (by the application of fertilizers) lead to greater rates of biodegradation of petroleum-polluted agricultural soils.
\end{abstract}

Keywords: Fertilizers; petroleum pollution; biodegradation; soil's physicochemical characteristics

\section{Nomenclature and abbreviations}

$\begin{array}{ll}\text { ANOVA } & \text { Analysis of variance } \\ \mathrm{C} & \text { Carbon } \\ \mathrm{C} / \mathrm{N} & \text { Carbon / Nitrogen } \\ \mathrm{Cfu} / \mathrm{ml} & \text { Colony forming unit per milli-litre } \\ \mathrm{CH}_{4} & \text { Methane } \\ \mathrm{EC} & \text { Electrical conductivity, } \mu \mathrm{S} / \mathrm{cm} \\ \text { g-level } & \text { Significance level } \\ \mathrm{HUB} & \text { Hydrocarbon-utilizing bacteria } \\ \mathrm{LSD} & \text { Least significant difference } \\ \mathrm{N} & \text { Nitrogen } \\ \mathrm{NPK} & \text { Nitrogen, phosphorus, potassium } \\ \mathrm{pH} & \text { Measure of acidity } \\ \mathrm{r} & \text { Correlation coefficient }\end{array}$




$\begin{array}{ll}\text { THB } & \text { Total heterotrophic bacteria } \\ \text { THC } & \text { Total hydrocarbon content, } \mathrm{mg} / \mathrm{kg} \\ \mathrm{t} & \text { The time elapsed after remediation } \\ \mathrm{y} & \text { Regression parameter }\end{array}$

\section{The Problem}

All things in nature ultimately succumb to decay, but surprisingly little is known about what can be done to accelerate the process. Atlas and Bartha [1] concluded that the disappearance of crude-oil from seawater could be accelerated by the addition of nutrients, such as nitrogen or phosphorus or both. Recommendations have been advocated for the microbial seeding of oil spills, because bacteria and fungi are the only biological species which have the metabolic capability of utilizing petroleum carbon for cell synthesis [2]. Also, oil spills result in an imbalance in the carbon-nitrogen ratio at the spill site, because crude-oil is essentially a mixture of carbon and hydrogen. This causes a nitrogen deficiency in an oil-soaked soil, which retards the growth of bacteria and the utilization of carbon source(s). In addition to a nitrogen deficiency in oil-soaked soil, certain nutrients like phosphorus may be growth-rate limiting [2]. Furthermore, large concentrations of biodegradable organics in the top layer of agricultural soils deplete oxygen reserves in the soil and slow down the rates of oxygen diffusion to deeper layers [3]. Crude-oil pollution tends to persist in soils until remediation measures, involving the application of nutrients are resorted to, because oxygen and nitrogen are limiting factors in all types of petroleum degradation.

The application of a fertilizer plus implementing certain agro-technical processes like tilling, were as effective as the use of bio-augmentation with indigenous hydrocarbonutilizing bacteria (HUB) plus fertilizer application and tilling, in the degradation of the hydrocarbon contaminant. This is because HUB is present in almost all types of soils in tropical rain-forests and would multiply where the right types and concentrations of metabolic feedstock exist [4]. This research is highly relevant to the Niger Delta region of Nigeria, where frequent oil-spills arising from crude-oil exploration-and-development activities have devastated farm lands and other agricultural settlements [5]. Hence, biostimulation with agricultural fertilizers was investigated in this remediation study. The aims were:

- To evaluate the process of biostimulation achieved by the addition of agricultural fertilizers to petroleum-polluted agricultural soils.

- To determine the total quantity and application rate of the fertilizer and other environmental conditions that would be effective, and the optima for the biodegradation process.

- To study the types of HUB, and to relate the total heterotrophic bacterial counts to the fertilizer applications. 


\section{Materials and Methods}

\section{Study Area}

This investigation was undertaken at the research farm of the Rivers State University of Science and Technology, Port Harcourt, Nigeria. Port Harcourt is the capital of Rivers State and economical the most important city in the Niger Delta region of Nigeria. From this region, more than $98 \%$ of Nigeria's current economic mainstay, namely crude-oil, is derived. Port Harcourt is within the tropical rain-forest zone with an ambient environment having: a mean annual rainfall of $2400 \mathrm{~mm}$; a mean monthly relative humidity of $85 \%$; a mean daily minimum temperature of about $23^{\circ} \mathrm{C}$ and a mean daily maximum temperature of $31.5^{\circ} \mathrm{C}$ [6]. The soil is normally moisture laden due to the high annual rainfall, which results in surface run-offs, rivulets and streams, which may convey substances like crude-oil to contaminate nearby land and rivers [4].

\section{Experimental Design}

The tested soil was divided into six treatment sample-cells, each horizontally extending $40 \mathrm{~cm} \times 40 \mathrm{~cm}$ and depth $30 \mathrm{~cm}$. The cells were such that the depth and exposed surfacearea of the soil, and in turn its temperature, nutrient concentration, moisture content and oxygen availability, could be controlled [7]. Furthermore, the cells inhibited excess runoffs of the crude-oil contaminant: such run-offs were inevitable since the remediation study took place from June to August 2005, in the open air and so exposed to the rains. Cell $\mathrm{O}$ was the control volume, i.e. did not receive any treatment, whereas cells $\mathrm{A}, \mathrm{B}, \mathrm{C}$, $\mathrm{D}$ and $\mathrm{E}$ were earmarked to receive $50 \mathrm{~g}, 75 \mathrm{~g}, 100 \mathrm{~g}, 150 \mathrm{~g}$ and $200 \mathrm{~g}$ of $20-10-10 \mathrm{NPK}$ fertilizer respectively, twice during the remediation period, i.e. at two-week intervals.

\section{Soil Treatment}

Prior to the fertilizer application, $800 \mathrm{~cm}^{3}$ (i.e. 0.8 litres) of Bonny light crude-oil was sprinkled upon the earth in each of the cells (including the control cell) from a perforated can at the rate of 0.8 litres of crude-oil per $0.16 \mathrm{~m}^{2}$ of soil: hence, the surface of the earth in each cell was completely covered with a thin layer of oil. The objective was to simulate conditions of a major spill. The cells were left undisturbed (i.e. in the open air) for three days. Then the treatments i.e. different amounts of fertilizer were applied but equal rates of tilling were used. The various treatment cells were tilled twice a week with cutlasses and shovels to provide the necessary aeration and mixing of nutrients and microbes with the contaminated soil. The aforementioned quantities of fertilizer were applied, sprinkled to the relevant cells and well worked to at least $30 \mathrm{~cm}$ depth in each cell. Thus, the equivalent of $6.25 \mathrm{ton} / \mathrm{ha}, 9.375 \mathrm{ton} / \mathrm{ha}, 12.5 \mathrm{ton} / \mathrm{ha}, 18.75 \mathrm{ton} / \mathrm{ha}$ and 25 ton/ha were applied to the cells A, B, C, D and E respectively. These amounts of fertilizer supplied $1250 \mathrm{~kg} / \mathrm{ha}, 1875 \mathrm{~kg} / \mathrm{ha}, 2500 \mathrm{~kg} / \mathrm{ha}, 3750 \mathrm{~kg} / \mathrm{ha}$ and $5000 \mathrm{~kg} / \mathrm{ha}$ of nitrogen for the six- week remediation period.

\section{Soil Samples}

These were obtained using a 22-cm hand-dug soil auger and put in labelled polyethylene bags. The samples for the Total Hydrocarbon Content (THC) measurements were placed in one litre glass bottles and sealed with aluminium foil. This procedure was undertaken 
three times to form three replicates. The bags and glass bottles were immediately transferred to the laboratory for analysis.

\section{Analysis of Soil Characteristics}

Measures were made of some of the soil's physicochemical parameters, such as particlesize distribution; THC; concentrations of organic carbon, nitrogen and moisture in the soil; the soil's pH value; its electrical conductivity and bacteria counts. Particle-size analyses were obtained by the Bouyoucous hydrometer method, as modified by Day [8]. The THC was measured using the procedure described by Odu et al [9], while the organic-carbon content was determined by the wet combustion method of Walkey and Black [10]. The total nitrogen and moisture contents as well as the soil's $\mathrm{pH}$ value and electrical conductivity were determined using methods adapted from Odu et al [9], Smith and Smith [11] and Jackson [12] respectively. The microbial analyses and bacterial counts were carried out following the procedure described by Harrigan and McCane [13], Cowan [14] and Buchanan and Gibbons [15].

Least Significant Difference (LSD), Analysis of Variance (ANOVA) and Correlation Coefficient methods were employed to analyze the measured data [16]. These were used to determine the relationship between time and the soil characteristics during the remediation process.

\section{$\underline{\text { Results and Discussion }}$}

The soil's characteristics that were used as indicators of the levels of pollution and remediation, before and after the crude-oil contamination, as well as during remediation process, are presented in Tables $1 \rightarrow 4$. The particle-size analyses of the $30 \mathrm{~cm}$ thick, top layer of the soil before treatment showed that the soil texture is silty clay (see Table 1).

The soil's moisture-content prior to contamination averaged $13 \%$. It dropped to about $8 \%$ (in cell A) after contamination, prior to remediation, and increased later in all the cells during remediation because of the rainfall. Rowell [17] reported that in heavily-polluted soils, water droplets adhere to the hydrophobic layer, and this prevents the wetting of the soil aggregates. As a result, during the study, the cells were remediated through the introduction of fertilizers and tilling. This process continued throughout the month of July, during which the maximum rate of rainfall occurs in this part of Nigeria [6], and resulted in the significant increases in the moisture content, i.e. to as high as $19 \%$ in cell A. Such moisture conditions are typical of silty-clay soils due to their high moistureretention capacity. There was a correlation $(\mathrm{r}=+0.073)$ between soil moisture content and the remediation period, which was not significant either at the $1 \%$ or $5 \%$ probability levels (Table 5). 
Table 1: Physicochemical characteristics of the silty-clay soil before its crude-oil contamination

(Results represent the means \pm standard deviation of treatment cells)

\begin{tabular}{|c|c|c|c|c|c|c|c|c|c|}
\hline \multicolumn{4}{|c|}{ Percentage $(\%)$ by mass } & \multirow{2}{*}{$\begin{array}{c}\mathrm{pH} \\
1: 2.5\end{array}$} & \multirow{2}{*}{$\begin{array}{l}\mathrm{EC} \\
\mu \mathrm{S} / \\
\mathrm{cm}\end{array}$} & \multirow{2}{*}{$\begin{array}{l}\text { THC } \\
\mathrm{mg} / \\
\mathrm{kg}\end{array}$} & \multicolumn{2}{|c|}{ Percentage by mass } & \multirow{2}{*}{$\approx \mathrm{C} / \mathrm{N}$ ratio } \\
\hline Sand & Silt & Clay & Moisture & & & & Organic $\mathrm{C}$ & $\begin{array}{c}\text { Total } \\
\mathrm{N}\end{array}$ & \\
\hline $\begin{array}{r}12.4 \\
+0.4\end{array}$ & $\begin{array}{l}40.1 \\
+0.2\end{array}$ & $\begin{array}{r}47.5 \\
+0.5\end{array}$ & $\begin{array}{l}13 \\
\pm 1\end{array}$ & $\begin{array}{c}4.7 \\
+0.1 \\
\end{array}$ & $\begin{array}{r}28 \\
+2\end{array}$ & $\begin{array}{c}84 \\
+10\end{array}$ & $\begin{array}{c}0.19 \\
+0.02\end{array}$ & $\begin{array}{c}0.38 \\
+0.03\end{array}$ & $\begin{array}{c}0.5 \\
+0.01\end{array}$ \\
\hline
\end{tabular}

Table 2: Soil's physicochemical characteristics 3 days after contamination, but prior to any remediation being undertaken

(Results represent the means \pm standard deviation of three replicates)

\begin{tabular}{|c|c|c|c|c|c|c|c|}
\hline & \multirow{2}{*}{$\begin{array}{c}\% \text { moisture } \\
\text { by mass }\end{array}$} & $\begin{array}{c}\mathrm{pH} \\
1: 2.5\end{array}$ & $\begin{array}{c}\mathrm{EC} \\
\mu \mathrm{S} / \mathrm{cm}\end{array}$ & $\begin{array}{c}\mathrm{THC} \\
\mathrm{mg} / \mathrm{kg}\end{array}$ & Organic C & Total N & \multirow{2}{*}{$\approx \mathrm{C} / \mathrm{N}$ ratio } \\
\cline { 1 - 1 } $\mathrm{O}$ & $12 \pm 2$ & $5.93 \pm 0.20$ & $75 \pm 4$ & $14,433 \pm 20$ & $0.38 \pm 0.05$ & $0.20 \pm 0.01$ & $2 \pm 0.5$ \\
\hline $\mathrm{A}$ & $8 \pm 1$ & $5.84 \pm 0.25$ & $71 \pm 3$ & $10,259 \pm 50$ & $0.31 \pm 0.02$ & $0.19 \pm 0.01$ & $2 \pm 0.5$ \\
\hline $\mathrm{B}$ & $11 \pm 1$ & $5.89 \pm 0.10$ & $71 \pm 5$ & $14,707 \pm 150$ & $0.35 \pm 0.04$ & $0.21 \pm 0.02$ & $2 \pm 0.4$ \\
\hline $\mathrm{C}$ & $10 \pm 2$ & $6.01 \pm 0.15$ & $79 \pm 2$ & $15,414 \pm 100$ & $0.39 \pm 0.05$ & $0.19 \pm 0.03$ & $2 \pm 0.6$ \\
\hline $\mathrm{D}$ & $17 \pm 1$ & $5.88 \pm 0.25$ & $73 \pm 3$ & $14,070 \pm 100$ & $0.42 \pm 0.03$ & $0.24 \pm 0.01$ & $2 \pm 0.2$ \\
\hline $\mathrm{E}$ & $18 \pm 1$ & $5.91 \pm 0.20$ & $78 \pm 4$ & $13,089 \pm 250$ & $0.39 \pm 0.03$ & $0.22 \pm 0.04$ & $2 \pm 0.3$ \\
\hline
\end{tabular}

Table 3: Soil's physicochemical characteristics 2 weeks after remediation (Results represent the means \pm standard deviation of three replicates)

\begin{tabular}{|c|c|c|c|c|c|c|c|}
\hline \multirow[b]{2}{*}{ Cell } & \multirow{2}{*}{$\begin{array}{c}\% \text { moisture } \\
\text { by mass }\end{array}$} & \multirow{2}{*}{$\begin{array}{c}\mathrm{pH} \\
1: 2.5\end{array}$} & \multirow{2}{*}{$\begin{array}{c}\mathrm{EC} \\
\mu \mathrm{S} / \mathrm{cm}\end{array}$} & \multirow{2}{*}{$\begin{array}{c}\mathrm{THC} \\
\mathrm{mg} / \mathrm{kg}\end{array}$} & \multicolumn{2}{|c|}{ Percentage } & \multirow{2}{*}{$\approx \mathrm{C} / \mathrm{N}$ ratio } \\
\hline & & & & & Organic $\mathrm{C}$ & Total N & \\
\hline $\mathrm{O}$ & $12 \pm 2$ & $5.51 \pm 0.10$ & $40 \pm 7$ & $15,565 \pm 40$ & $0.032 \pm 0.003$ & $0.190 \pm 0.05$ & $4 \pm 0.5$ \\
\hline A & $16 \pm 1$ & $5.42 \pm 0.05$ & $106 \pm 13$ & $6,063 \pm 100$ & $0.268 \pm 0.01$ & $0.090 \pm 0.007$ & $3 \pm 0.6$ \\
\hline B & $20 \pm 1$ & $5.35 \pm 0.10$ & $31 \pm 4$ & $7,928 \pm 250$ & $0.270 \pm 0.05$ & $0.068 \pm 0.06$ & $4 \pm 0.6$ \\
\hline $\mathrm{C}$ & $14 \pm 1$ & $5.49 \pm 0.20$ & $96 \pm 5$ & $7,125 \pm 200$ & $0.280 \pm 0.02$ & $0.072 \pm 0.006$ & $4 \pm 0.4$ \\
\hline $\mathrm{D}$ & $18 \pm 2$ & $5.56 \pm 0.15$ & $32 \pm 4$ & $4,535 \pm 180$ & $0.315 \pm 0.01$ & $0.086 \pm 0.007$ & $4 \pm 0.5$ \\
\hline E & $16 \pm 1$ & $5.70 \pm 0.10$ & $215 \pm 15$ & $1,659 \pm 210$ & $0.305 \pm 0.06$ & $0.068 \pm 0.006$ & $4 \pm 0.6$ \\
\hline
\end{tabular}


Table 4: Soil physicochemical characteristics 6 weeks after remediation

(Results represent the means \pm standard deviation of three replicates)

\begin{tabular}{|c|c|c|c|c|c|c|c|}
\hline \multirow[b]{2}{*}{ Cell } & \multirow{2}{*}{$\begin{array}{c}\% \text { moisture } \\
\text { by mass }\end{array}$} & \multirow{2}{*}{$\begin{array}{c}\mathrm{pH} \\
1: 2.5\end{array}$} & \multirow{2}{*}{$\begin{array}{c}\mathrm{EC} \\
\mu \mathrm{S} / \mathrm{cm}\end{array}$} & \multirow{2}{*}{$\begin{array}{c}\mathrm{THC} \\
\mathrm{mg} / \mathrm{kg}\end{array}$} & \multicolumn{2}{|r|}{ Percent } & \multirow{2}{*}{$\approx \mathrm{C} / \mathrm{N}$ ratio } \\
\hline & & & & & Organic C & Total N & \\
\hline $\mathrm{O}$ & $18 \pm 0.5$ & $5.74 \pm 0.10$ & $23 \pm 5$ & $19,414 \pm 90$ & $0.19 \pm 0.05$ & $0.032 \pm 0.003$ & $6 \pm 0.8$ \\
\hline A & $19 \pm 0.5$ & $5.95 \pm 0.15$ & $72 \pm 6$ & $530 \pm 30$ & $0.14 \pm 0.04$ & $0.030 \pm 0.002$ & $5 \pm 0.6$ \\
\hline B & $16 \pm 1$ & $5.85 \pm 0.25$ & $90 \pm 9$ & $1,043 \pm 180$ & $0.18 \pm 0.05$ & $0.030 \pm 0.002$ & $6 \pm 0.8$ \\
\hline $\mathrm{C}$ & $16 \pm 1$ & $5.94 \pm 0.30$ & $94 \pm 8$ & $1,202 \pm 150$ & $0.18 \pm 0.05$ & $0.030 \pm 0.002$ & $6 \pm 0.7$ \\
\hline $\mathrm{D}$ & $16 \pm 1$ & $6.08 \pm 0.30$ & $97 \pm 6$ & $5,236 \pm 220$ & $0.20 \pm 0.06$ & $0.034+0.003$ & $6 \pm 0.6$ \\
\hline $\mathrm{E}$ & $14 \pm 1.5$ & $6.05 \pm 0.30$ & $256 \pm 12$ & $6,581 \pm 200$ & $0.22 \pm 0.07$ & $0.037 \pm 0.005$ & $6 \pm 0.5$ \\
\hline
\end{tabular}

The soil's $\mathrm{pH}$ increased in all the cells after contamination with crude-oil. It later decreased during the remediation treatment: after the six weeks total remediation period, it increased in all the options once again ( see Tables $1 \rightarrow 4$ ). Tisdale and Nelson [18] made a similar observation and reported that the decrease in $\mathrm{pH}$ during remediation treatment may have resulted from the production of acid radicals through the process of nitrification of the applied fertilizer. There was no significant change in the effect of remediation treatment on the soil's $\mathrm{pH}$ value at $5 \%$ probability levels. Similarly, the electrical conductivity (EC) of the earth in the cells generally increased. The soluble salt-content in the soil, which was due to the introduction of the inorganic fertilizer, caused the general increase in the EC. Odu et al [9] made a similar observation. There was a correlation $(r=+0.106)$ between soil's EC and time elapsed (see Table 5).

A sharp increase in the soil's carbon (C) content resulted from the crude-oil contamination; so corroborating Jobson et al [2]. However, the organic carbon content dropped to near background conditions during the remediation treatment. In this study, the relationship between organic carbon content and remediation period showed a correlation $(r=-0.187)$. This suggests that the amount of carbon reduced with time (see Table 5). On the other hand, the total nitrogen $(\mathrm{N})$ content for the various options decreased upon prolonging the period of remediation, contrary to expectation that it would naturally increase with the application of the nitrogenous fertilizer. A hypothesis that would account for such behaviour is that the bacterial population was readily utilizing the available nitrogen for hydrocarbon degradation: hence the available nitrogen was diminishing with time. Brady and Weil [19] made a similar observation and concluded that, during biodegradation, nitrogen may be lost to the atmosphere when nitrate ions are converted to gaseous forms of nitrogen by a series of widely-occurring biochemical-reduction reactions, brought about by denitrifying bacteria, such as pseudomonas, bacillus and micrococcus, especially when localized micro-sites of low oxygen exist well within the soil aggregates. The correlation 
analysis, between the total nitrogen content and remediation period, showed a negative relationship $(\mathrm{r}=-0.341)$ at a $5 \%$ probability level (Table 5).

Table 5: The relationships between time elapsed after remediation to measured soil characteristics during remediation as expressed by correlation coefficients and regression: the $\mathrm{g}$ level is not significant at the $1-5 \%$ probability levels

\begin{tabular}{|c|c|c|}
\hline $\begin{array}{c}\text { Correlation regression } \\
\text { factor }\end{array}$ & $\begin{array}{c}\text { Correlation } \\
\text { coefficient, } \mathrm{r}\end{array}$ & Significance equation \\
\hline time vs. moisture & +0.073 & $\mathrm{y}=17.1+0.3 \mathrm{x}$ \\
\hline time vs. $\mathrm{pH}$ & +0.037 & $\mathrm{y}=5.54+0.05 \mathrm{x}$ \\
\hline time vs. THC & -0.260 & $\mathrm{y}=3170-255 \mathrm{x}$ \\
\hline time vs. organic C & -0.187 & $\mathrm{y}=0.196-0.01 \mathrm{x}$ \\
\hline time vs. total N & -0.341 & $\mathrm{y}=0.037-0.0 \mathrm{x}$ \\
\hline time vs. C/N ratio & +0.182 & $\mathrm{y}=4.0+0.2 \mathrm{x}$ \\
\hline time vs. EC & +0.106 & $\mathrm{y}=98.6+2.6 \mathrm{x}$ \\
\hline
\end{tabular}

There was a marked decrease in the percentage of the THC in all the earth samples in the cells except for that in the control cell, for which the THC increased. After six weeks of remediation, the percentage THC reductions for the treatment cells were $95 \%, 93 \%, 92 \%$, $63 \%$, and $50 \%$ for cells A, B, C, D and E respectively (see Figure 1). The results indicate that the applied fertilizer increased the degradation of the hydrocarbons since the THC of the control cell that received no fertilizer treatment was on the increase. The continuous rise of the THC of the control cell was due to the existing anaerobic conditions, these resulted because the control-cell earth was not tilled at all, so there was insufficient oxygen supply and hence anaerobic decomposition ensued resulting in organic materials (methane $\left(\mathrm{CH}_{4}\right)$ and carbon dioxide, the former - a hydrocarbon) being produced and hence the increase in the THC.

It is evident, from Table 6, that different concentrations of fertilizer affect the rate of degradation. The behaviour of the cells, after two weeks of remediation, and at the end of the remediation period, reveals that certain optima exist, which, when exceeded, cause diminishing returns. From the results in Table 6, it can be inferred that for quantities of fertilizer between $200 \mathrm{~g}$ and $300 \mathrm{~g}$ per $0.16 \mathrm{~m}^{2}$, there was an excess of nutrients, which probably reduced the activity of the microbes in the soil. The THC was increasing in cells $\mathrm{D}$ and $\mathrm{E}$ at six weeks after remediation. Vance [20] observed a similar behaviour: the sudden increase in contaminant concentration was probably induced by the high levels of bacterial activity stimulated in the hydrocarbon-rich soil. The microbes excreted extracellular surfactant-like polymers during their metabolic cycle: these resulted in the hydrocarbons being of low concentrations in the cells from which the samples were collected. 
Table 6: Percentage THC Reductions

\begin{tabular}{|c|c|c|}
\hline \multirow{2}{*}{ Treatment Cell } & \multicolumn{2}{|c|}{ Sampling Period (Weeks) } \\
\cline { 2 - 3 } A & 2 & 6 \\
\hline B & 41 & 95 \\
\hline C & 46 & 93 \\
\hline D & 54 & 92 \\
\hline E & 68 & 63 \\
\hline
\end{tabular}

Results of the total heterotrophic bacteria (THB) count showed that there was a general increase in the THB in all the cells (Table 7). However, cell E and the control cell exhibited different behaviours. The control cell, of those tested, increased at the lowest rate. Odokuma and Dickson [4] observed a similar behaviour and noted that the relatively low values obtained in the control cell may have resulted from the toxicity of the crude-oil to the soil microbes, brought about by the high concentration of the crude-oil before the remediation treatment. For cell E, the increase in the THB count was significant within the first two weeks. It later increased at a slower rate during the remaining four weeks. This may have been due to the retardation of microbial activity resulting from the high concentration of ammonia gas released from the fertilizer, because most commercial fertilizers supply nitrogen in soluble forms, such as nitrate or ammonium. This has been reported previously by Brady and Weil [19]. The hydrocarbon-utilizing bacterial types isolated from the soil samples were bacillus, corynebacterium, pseudomonas, flavobacterium, micrococcus, acinetobacter and aerococcus. 


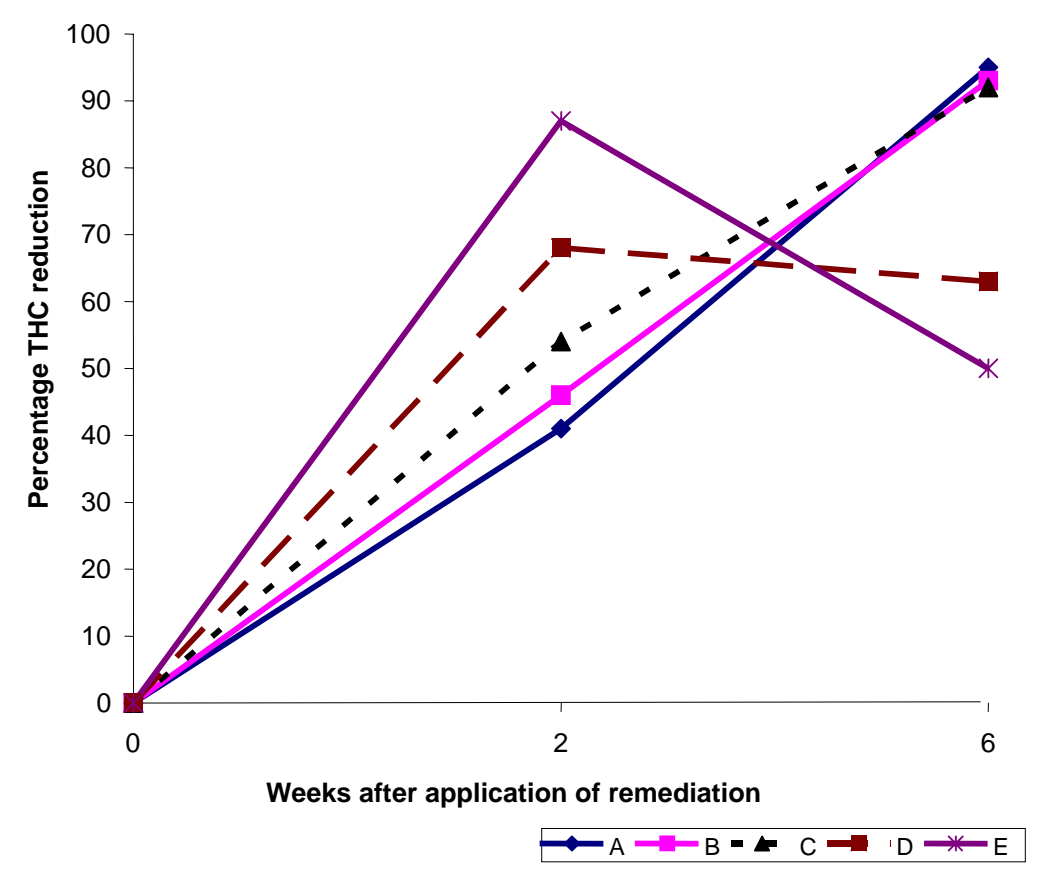

Figure 1: Rate of hydrocarbon loss

Table 7: Total heterotrophic bacterial count.

\begin{tabular}{|c|c|c|c|}
\hline \multirow{2}{*}{ Cell } & \multicolumn{3}{|c|}{ Sampling Period (Weeks) } \\
\cline { 2 - 4 } & \multicolumn{2}{|c|}{ Heterotrophic bacteria count $\left(10^{5} \mathrm{Cfu} / \mathrm{ml}\right)$} \\
\cline { 2 - 4 } O & 8.9 & 12.8 & 15.3 \\
\hline A & 3.5 & 18.6 & 26.8 \\
\hline B & 6.2 & 16.2 & 26.4 \\
\hline C & 5.9 & 17.0 & 28.4 \\
\hline D & 10.1 & 19.4 & 28.4 \\
\hline E & 4.8 & 19.6 & 21 \\
\hline
\end{tabular}

The background (i.e. pre- contaminated) samples had a bacterial count of $3.3 \times 10^{5} \mathrm{Cfu} / \mathrm{ml}$.

\section{Conclusions and Recommendations}

Nutrient-enhanced bioremediation can achieve the degradation of petroleum hydrocarbons in agricultural soils. What is necessary is the supply of the right type(s), quantities or 
application rates of fertilizer and also the provision of other suitable environmental conditions for the accelerated development of soil microbes.

The results of the THC (i.e. the basic index of evaluation) of the individually-treated cells show that cell A (which received $100 \mathrm{~g}$ of fertilizer) recorded the highest THC loss $(95 \%)$. Cell B (which received $150 \mathrm{~g}$ of fertilizer or $9.375 \mathrm{ton} / \mathrm{ha}$ ) experienced a hydrocarbon loss of $93 \%$. The application of $200 \mathrm{~g}$ or $12.5 \mathrm{ton} / \mathrm{ha}$ (Cell C) produced a $92 \%$ hydrocarbon loss. Cell D (which received 18.75 ton/ha or $300 \mathrm{~g}$ of fertilizer) had a $63 \%$ loss. Cell E (which received $400 \mathrm{~g}$ or $25 \mathrm{ton} / \mathrm{ha}$ ) recorded the lowest rate (i.e. 50\%) of hydrocarbon degradation after the six-week period. Thus between 75 and $200 \mathrm{~g}$ of fertilizer per $0.16 \mathrm{~m}^{2}$ (i.e. $4.7 \rightarrow 12.5$ ton/ha) will lead to the fastest biodegradation. For this to occur, certain optima should apply, i.e. a $\mathrm{pH}$ value in the range $5.5 \rightarrow 6.0$, moisture content between 14 and $19 \%$ during the wet season and a tillage rate of between 2 and 5 times a week.

For an effective bioremediation:

- Nitrogenous-based fertilizers (preferably NPK type) should be used and an application of between 4.7 and 12.5 ton/ha should be resorted to achieve an accelerated biodegradation.

- Bioremediation should be applied during the dry season, because a wet soil induces anaerobic conditions that impede accelerated biodegradation. When done during the wet season, the rate of tillage or soil aeration should be increased to about five times a week to facilitate adequate mixing of the nutrients and microbes with the contaminated soil and also to enhance the diffusion rate of oxygen to the deeper layers.

\section{$\underline{\text { References }}$}

1. Atlas R. M and Bartha R (1972), Degradation and mineralization of petroleum in seawater: limitation by nitrogen and phosphorus. Biotechnol. Bio eng. 14: pp. $309-$ 318 .

2. Jobson, A., Mclauglin, M., Cook, F. D. and Westlake, D. W. S. (1974), Effect of Amendments on the microbial utilization of oil applied to soil. App. Microbiology vol. 27, No 1. pp. 166-171.

3. Molnaa B. A. and Grubbs R.B. (1989), Bioremediation of petroleum contaminated soils using microbial consortia as innoculum. Solmar Corporation, U.S.A.

4. Odokuma, L. O. and Dickson, A. A. (2003), Bioremediation of a crude-oil polluted tropical rain-forest soil. Global Journal of Environmental Sciences, Vol. 2, No. 1: $29-40$.

5. Ayotamuno, M.J., Akor, A.J. and Igho T.J. (2002), Effluent quality and wastes from petroleum-drilling operations in the Niger Delta, Nigeria. Environment Management and Health, Vol. 13, No. 2 pp $207-216$. 
6. Federal Ministry of Aviation (2005), Meteorological data of Port Harcourt Metropolis for years 2003 and 2004.

7. Mattewson, J. R. and Grubbs, R. B. (1988), Innovative techniques for the bioremediation of contaminated soils. Presented at $2^{\text {nd }}$ annual CWPCA industrial and hazardous-waste information exchange, Oakland, USA.

8. Day, P. R. (1965), Particle fractionation and particle-size analysis. In Methods of Soil Analysis, part 1. (C.A. Black et al ed.) American Soc. of Agronomy Inc. Madison, Wisconsin, U.S.A. pp. 545 - 567.

9. Odu C. T. I., Esuruoso, O. F., Nwoboshi, L. C. and Ogunwale, J. A. (1985), Environmental study of the Nigerian Agip Oil Company operational areas. Proc. 'Soils and Fresh Water Vegetation', Conference, Milan, Italy.

10. Walkey, A. and Black, I. A (1934), Determination of organic carbon in soil. Soil Sci., 37: 29-38.

11. Smith, G. N and Smith, I. G. N. (1998), Elements of Soil Mechanics. $7^{\text {th }}$ ed., Blackwell Science, Oxford. pp. 9-10.

12. Jackson M. L (1964), Soil Chemical Analysis, Prentice Hall, New York. pp. 498.

13. Harrigan, W. F and McCane, M. E (1990), Laboratory Methods in Food and Dairy Microbiology, $8^{\text {th }}$ Edition. Academic Press, London.

14. Cowan, S. T. (1974), Manual for the Identification of Medical Bacteria. Cambridge University Press, Cambridge.

15. Buchanan R. V and Gibbons N. E (1994), Bergrey's Manual of Determinative Bacteriology, Williams and Wilkins Co., Baltimore, USA.

16. Wahua T. A. T (1999), Applied Statistics for Scientific Studies. Afrika-link books, Owerri, Nigeria. pp. 250-287.

17. Rowell, M. J. (1977), The effect of crude-oil spills on soil: a review of the literature. The Reclamation of Agricultural Soil after Oil Spills, part 1: Research, Toogood J.A., ed., API publication, vol. 1 pp.27.

18. Tisdale, S. and Nelson, W. (1975), Soil Fertility and Fertilizer, $3^{\text {rd }}$ ed., Macmillan Pub. Co., Inc. New York, USA.

19. Brady N. C and Weil R. R (1999), The Nature and Properties of Soils. $12^{\text {th }}$ ed., Prentice Hall Publishers, London, pp. 1 - 9, 453-536, 727, 739-740.

20. Vance D. B (2002), On-side above-ground bioremediation of excavated oil-andgrease contaminated soils, http://2the4.net/biocell.htm 